\title{
Urban Flood Event and Associated Damage in the Benue Valley, Nigeria
}

\section{Temi Ologunorisa}

Federal University of Technology Akure

Obioma Ogbuokiri

Federal University of Technology Akure

Adebayo Oluwole Eludoyin ( $D$ oaeludoyin@yahoo.com )

Obafemi Awolowo University https://orcid.org/0000-0003-0532-7689

\section{Research Article}

Keywords: Recurring flood disasters, Flood damage, Poor and vulnerable communities, Response strategies

Posted Date: March 23rd, 2021

DOI: https://doi.org/10.21203/rs.3.rs-272269/v1

License: (9) This work is licensed under a Creative Commons Attribution 4.0 International License.

Read Full License

Version of Record: A version of this preprint was published at Natural Hazards on September 25th, 2021. See the published version at https://doi.org/10.1007/s11069-021-05052-6. 
1 Urban flood event and associated damage in the Benue valley, Nigeria

2 T.E Ologunorisa

3 Department of Meteorology and Climate Science,

$4 \quad$ Federal University of Technology, Akure, Nigeria

5 E-mail: ologunorisa1966@gmail.com

6

7 O. Obioma

8 Department of Meteorology and Climate Science,

9 Federal University of Technology, Akure, Nigeria

10 E-mail: obiomsa1@gmail.com

11

$12 \quad{ }^{1}$ A.O. Eludoyin

13 Department of Geography

14 Obafemi Awolowo University, Ile-Ife, Nigeria

15 E-mail: oaeludoyin@yahoo.com

16

17

18

19

20

${ }^{1}$ Corresponding author 
22 Abstract

23 Flooding events in the Lower Benue valley of Nigeria are often associated with huge damage to 24 properties and loss of life in the adjoining communities. Specific objective of this study is to 25 evaluate the impact of 2017 flood event as typical of the study area. Method used was an 26 integrated environmental approach that combines analysis of rainfall and discharge data with 27 social surveys, remote sensing and geographical information system. Standardized Precipitation 28 Index (SPI), Precipitation Concentration Index (PCI) as well as flood damage curves were analysed with landuse/cover change and soil data to establish the nature of the flood and its impacts. Result showed that the flood in the study area is essentially saturation overland flow, which is more associated with saturation-excess than infiltration excess flow, and that the flood events are recurrent and predictable. $85 \%$ of the affected residents are however poor, earning an equivalent of US $\$ 4.3$ daily, and live in non-reinforced concrete masonry (64\%) and wooden buildings (24\%). Many of the affected communities lived within flood plain and most buildings were structurally deficient. Victims received no compensation, and the properties were generally uninsured. The study recommends extensive flood control policy for the area and similar floodprone communities.

Keywords: Recurring flood disasters, Flood damage, Poor and vulnerable communities; Response strategies

\section{Introduction}

\subsection{Background}

Flood, inundation or overflow of water resulting from different overland flow mechanisms, is associated with frequent disastrous effects (Barredo, 2007; Berz, 2020; Yin, 2020; Zeleňáková et 
al, 2020), including causing essential damages to livelihoods, properties, and some cases, deaths. Overland flow mechanisms such as infiltration-excess, saturation-excess and preferential flows become dominant in different soil and vegetation environment; largely impervious or loosely vegetated but dry surfaces, near-stream humid and vegetated surface as well as areas characterised by natural or artificial mole or pipes, respectively (Beven, 1986; Hussaini \& Khan, 2020). Floods generally result from the interaction of physical processes, including certain hydrological pre-conditions, meteorological or climate factors, runoff generation processes and river routing at different scales (Nied et al., 2014). While floods are initiated by precipitation excess or dam failure (Kunkel et el., 1999; Ologunorisa, 2001; Ologunorisa \& Tersoo, 2006; Adelekan, 2015; Albright \& Crow, 2019; Tei et al., 2020), the effects are largely exacerbated by blocked drainage systems and poorly planned settlements, among other urban planning problems (Costa, 1985; Brown \& Graham, 1988; Adelekan, 2011; Atufu \& Holt, 2018; Asiedu, 2020; Latrubesse et al, 2020).

Studies have shown that floods are not always disastrous; especially in areas such as parts of the agricultural areas of sub-Saharan Africa, Asia and South America where deposited alluvial plains in many flood-prone watersheds have accounted for productive farmlands (Fairbairn, 2005; Sommer et al., 2020). Floods also inundate wetlands with fresh wastes and nourish lakes and streams with nutrients, among some other positive impacts (Ponnamperuma, 1984; Bai et al., 2020. Firth et al., 2020). The impact (destructive or non-destructive) of flood is often dependent on the strength (intensity and stretch) of rainfall and the environmental responses (coping, adaptation or resilience) (Baker et al., 1988; Hu et al., 2019). Floods may also result into direct or indirect fatalities (Janerich et al, 1981; Jonkman \& Kelman, 2005; Davis et al, 2019; Knighton et al., 2020). The effects include $40 \%-47 \%$ of all weather-related disasters, loss of livelihoods 
67 of about 2.3 billion people and 242,000 deaths between 1995 and 2015 (United Nations Office for Disaster Reduction, UNISDR, 2015). The indirect effects include psychological and mental illness of victims of flood-related losses. Alderman et al. (2012) indicated that flood in many densely and poorly planned settlements may significantly correlate with increased risk of disease outbreaks, increased mortality and prolonged psychological distress.

Di Baldassarre et al (2010) argued that flood-related losses and fatalities have dramatically increased in Africa since about half of the century and that there is a growing global concern on the need to identify the causes for the increased amount of damages. According to the United Nations (2009) over 600,000 people were either displaced or suffered significant economic loss across the West Africa in September 2009, and about over 500 deaths occurred in flood-linked disasters in 2007. In general, fatalities due to flood appear to be an annual occurrence, probably due to poor understanding of the flood disasters alongside poor settlement planning system (Di Baldassarre et al., 2010). In Nigeria, coastal and urban floods have been linked to numerous disasters, such that the National Emergency Management Agency (NEMA) documented that flood events occurrence in four months (June - September) in 2012 directly caused more than 363 human deaths with displacement of at least 1.2 million people. Only in the state (Oyo State)'s capital of Ibadan in the southwestern Nigeria, more than a million people were severely affected by the 'Ogunpa flood' disasters in 1980 (Smit and Parnell, 2012; Nwala, 2017). Life and properties worth millions of dollars have also been lost to flood events in different parts of the countries, including the Niger Delta (Ologunorisa, 2001; Ologunorisa, 2004; Ologunorisa and Adeyemo, 2005), Lagos (Adelekan, 2016a, Olanrewaju et al, 2019), Ibadan (Adelekan, 2016b), Akure (Eludoyin et al., 2007), Abuja (Adeleye et al, 2019), Chad basin (Oyebande, 1991) and Yobe (Goes, 2002). 
with the prime aim of funding ecological projects to mitigate serious ecological problems that include flooding and soil erosion (www.ecologicalfund.gov.ng). Despite the efforts through the initiatives and other efforts of non-governmental agencies, the menace of flooding and associated

soil erosion has become a recurrent problem in almost all parts of the country, suggesting that the initiatives are probably not working. Records of flood-related fatalities (Di Baldassarre et al., 2010) revealed an increase in flood-related deaths in Nigeria and the entire African region since the preceding 50 years. A review of recent studies on possible factors that might link to increased fatalities during flood events revealed poor modeling or use of non-validated models (Bernhofen et al, 2018), changing climatic conditions and anthropogenic factors, such as poor land use management and urbanization that are capable of exacerbating the impact (Ekeu-wei, 2018).

\subsection{Research Problem}

104 administrative capital of Kogi and Makurdi States in the western and eastern flange of the middle belt of Nigeria have suffered severe flooding over the years (Onuigbo et al., 2017; Brooks et al., 2020; Lawal, 2020). The flooding events of August-September, 2017 resulted in the displacement of over 10,000 people, and the situation was described as being 'in dire need of humanitarian intervention' and 'desperately pathetic' (Davies, 2017). The disturbing level of the

111 impact of flood on the mid-belt environment of Nigeria in 2017 is not unique; such is 112 representative of the situation in many flood prone communities in the sub-Saharan Africa, 113 including coastal and urban settlements (Douglas et al., 2008; Hula \& Udoh, 2015; Kanu \& 
Imatari, 2016; Nkwunonwo et al., 2020; Plänitz, 2020). According to Nkwunonwo et al. (2020), sub-Saharan African countries, including Nigeria are challenged by poorly understood and under-studied flood hazards. Existing studies on disaster management have equally revealed problems with flood management, preparedness as well as coping strategies (Adeleye, 2019); many of the studies have linked the inadequate management of flood hazards to limited development control (designing and implementing sustainable policy for ensuring efficient regulations) of physical development (Ahmed and Dinye, 2011; Lekwot et al., 2013). Douglas et al (2008) posited that residents of low to middle economic settlements bare most burdens of flood hazards because disaster response and mitigating facilities are generally poor.

This study has focused on determining the impact of flood events on affected on communities in the Benue trough of Nigeria. Objectives were to analyse temporal characteristics of rainfall, the effects of the flood events as well as the perception of the residents on the causes and effects of flood hazards in the selected communities in the Benue trough of Nigeria. The study is based on the hypothesis of suggested by Lovett (2000) that the ability to combine data from different sources is adequate for effective environmental management. Consequently, the study is aimed at strengthening the importance of freely available satellite imageries, especially Landsat image data to complement climate and survey data for better decision for flood control development in the region. The hypothesis is supported by the argument by Douglas et al (2008) that flooding is related to heavy rainfall, extreme climatic events and changes in the built-up areas. The extent to which this hypothesis is true is determined in this study from an integrated perspective of climate analysis, remote sensing, social and field surveys, with geographical information system.

\section{Materials and Methods}




\subsection{Study Area}

The study area, Makurdi, situated at the narrow end of the River Benue lying on both sides of the riverbanks, is the administrative headquarter of Benue State (Figure 1). It is situated inside the floodplain of the Lower River Benue valley with a physiographic stretch of about $73 \mathrm{~m}-167 \mathrm{~m}$ above sea level, and is often drained by River Benue which partitions it into Makurdi North and South banks. Apart from River Benue, tributaries and headwater channels that drain the communities in Makurdi include Kpege, Adaka, Asase, Idye, Urudu, and Demekpe streams; the dense drainage system usually makes the area susceptible to inundation in the wet season.

\section{Insert Figure 1}

Dominant climate in the area is the Tropical Guinea Savanna, classified as Koppen's $A w$ climate. The Guinea belt occupies the limits of tropical rainforest climate, and extends to the central part of Nigeria where it forms a boundary with Sudan savanna climate, exhibiting a wellmarked single peak rainy season and a dry season. The 1951-2009 average minimum, mean and maximum temperature values are $22.3 \pm 2.5^{\circ} \mathrm{C}, 27.8 \pm 1.8^{\circ} \mathrm{C}$ and $33.3 \pm 2.6{ }^{\circ} \mathrm{C}$, respectively while mean relative humidity for same period is $69.8 \pm 14.2 \%$ (Eludoyin et al, 2014). Mean annual rainfall is about $1200 \mathrm{~mm}$, with double peaks and little dry season; the rainy season lasts from April to October, while dry season occurs between November and March. Geological underlain is primarily sedimentary, with micaceous and feldspathic sandstone in some portions of the area, and shale in some low-lying areas (Nyagba, 1995). Main soil types are hydromorphic soils that developed on alluvium sediments along River Benue coastline, as well as red ferasols away from the coastline (Nyagba, 1995). Given the influence of good drainage, rich soil and grassland that makes cultivation relatively easier than what obtains in the rainforest belt, over $60 \%$ of the indigenous people are small-scale or indigenous farmers, and many of the farmers are also 
160 fishermen, depending on their locations. Other residents are either government workers or 161 commercial workers, but a number of the residents combine at least two occupational activities.

162 The population density as at 2016 was estimated at 405,000 and projected to be about 600,000 by 163 2021, based on the 1991 Nigerian Population Commission's estimated growth of 3.05\% per year, 164 and net migration. Prior to the flood episode of August/September 2017, the study area 165 (Makurdi) has experienced flooding in many years, and significant damages were reported in 166 newsprints in 1996, 1999, 2000, 2002, 2004, 2005, 2007, 2008, 2012 and 2017 (Ologunorisa and

167 Tersoo, 2006; Shabu and Tyonum, 2013), especially as River Benue overflows its banks, due to 168 either heavy and prolonged rainfall or dam failure, such as the Lagdo dam failure in 2012, which 169 caused displacement of over 500 people and inundation of about 300 buildings (Ocheri and 170 Okele, 2012). The 2017 flooding event was next to that of 2012 in magnitude (Davies, 2017), 171 hence its selection for this study.

\subsection{Data}

173 Data used for this study include remotely sensed imageries of Shuttle Radar Topography 174 Mission, SRTM, and Landsat 8 Operational Land Imager (OLI, released on $15^{\text {th }}$ of January, 1752017 ; spatial resolution $=30 \mathrm{~m}$ ), which were used to derive essential topographical 176 characteristics, such as slope and drainage network (SRTM), as well as the land use/cover over 177 the study area. Both the Landsat and SRTM imageries for the study area were downloaded from 178 the archive of the United States of America's Geological Survey (USGS). Data also included 57 179 (1960 - 2017) daily rainfall and runoff data, as well as daily evaporation data for 36 years (1980 $180-2017)$ that were obtained from the office of the NigerianMeteorological Agency (NiMet) and 181 Nigerian Hydrological Service Agency (NiHSA) in Abuja Nigeria, respectively. Furthermore, 182 soil data and geological data were extracted from the Harmonised World Soil Database (HWSD) 
183 Nigerian Geological Survey Agency, respectively. In addition, 400 residents of the study area 184 were selected using a systematic sampling procedure for administration of a set of semi185 structured questionnaire. Contents of the questionnaire were grouped into personal and socio186 economic attributes of respondents, perception on vulnerability to flood disasters and coping 187 strategies.

\subsection{Data analysis}

190 The remote sensing data were first corrected for geometric and radiometric corrections as 191 required for standard remote sensing imageries for quality enhancement and assessment 192 (Burrough, 1996). The imageries were thereafter georeferenced in ArcGGIS software (version 193 10.5) by merging the coordinates of known points that were obtained from the existing 194 topographical maps of the area, and confirmed with the use of global positioning system (GPS, 195 Germin etrex version) on the physical structure as described by Stopher et al. (2015). Also, the 196 Landsat 8 imagery was classified using supervised classification (based on Maximum likelihood 197 Classification algorithm) into different dominant landuse system following Anderson (1976)'s 198 scheme for landuse/land cover classification. All the imagery data as well as soil and geological 199 data were analysed following the principles of remote sensing and geographical information 200 system in ArcGIS software as described in previous studies and the software's manual (Hillier, 201 2005; Crosier et al., 2006). The climate and discharge data were also investigated for non202 climatic heterogeneity and instrumental errors as advised by the World Meteorological 203 Organisation (1989) before analysed. The data were analysed for time series, dispersion using 204 standard extreme rainfall indices, mainly, Standardized Precipitation Index (SPI) and 
205 Precipitation Concentration Index (PCI). The PCI was determined based on the recommendation 206 of Oliver (1980) and De Luis et al. (2011) (equation 1)

$207 \quad P C I=\frac{\sum_{i=1}^{12} P_{i}^{2}}{\left(\sum_{i=1}^{12} P_{i}\right)^{2}} \times 100$

208 Where: $\mathrm{P}_{\mathrm{i}}=$ the rainfall amount of the $i$ th month. PCI less than $10 \%$ indicates low 209 precipitation concentration; $11-15 \%$ is interpreted as moderate and 16 and above is high.

210 The SPI is typically determined as probabilities, based on the likelihood of recorded 211 measure of precipitation; zero indicates the median precipitation amount and negative values 212 represent dry spell while positive values indicate wet condition over a period of at least 30 years 213 (McKee et al., 1993; Cheval et al., 2014). SPI was determined using equation 2.

$214 S P I=\frac{X-\bar{x}}{S D}$

215 Where: $(X-\bar{x})=$ the rainfall anomaly and SD $=$ standard deviation of the mean of the series.

216 In this study, monthly SPI were calculated for the period 1980 to 2017, using the rainfall data 217 obtained from the Makurdi station of the Nigerian Meteorological Agency; the body responsibly 218 for obtaining and keeping such records in the country. Also, the Mann - Kendall (MK) trend 219 test, a non-parametric test for determination of monotonic trends in a series of data was adopted 220 to assess statically significant trend of rainfall over the study period. The MK test is less affected 221 by the outliers than other tends' procedure (Birsan et al., 2005). The MK test statistic ' $\mathrm{S}$ ' is 222 calculated based as described by Yue et al. (2002) (3)

$223 S=\sum_{i=1}^{n-1} \sum_{j=i+1}^{n} \operatorname{sgn}\left(x_{j}-x_{i}\right)$

224 Where: 
$225 \quad \operatorname{Sgn}\left(x_{j}-x_{i}\right)=\left\{\begin{array}{c}+1 i f\left(x_{j}-x_{i}\right)>0 \\ 0 i f\left(x_{j}-x_{i}\right)=0 \\ -1 i f\left(x_{j}-x_{i}\right)<0\end{array}\right\}$

$226 X_{i}$ and $X_{j}$ are the annual values in years $i$ and $j(j>i)$ respectively.

227 Perceptions of residents were analysed using frequency/percentage distribution analysis. The 228 study area was also visited for visual assessment of flood damage after one of the occurrences in 2292017.

\section{3. Results}

\section{3.1. Rainfall and discharge characteristics}

232 Some mean monthly characteristics of daily rainfall within the selected period are provided in 233 Table 1. Rainfall averagely increased from March and peaked in August before it rescinded in 234 September and October. The generally low rainfall from November to March characterizes the 235 months as dry period. Coefficients of variation were higher in the dry period than in the other 236 months (wet or rainy season). The results of the M-K test and Sen's slope that were used to 237 examine monotonic trend and its magnitude indicate that while there is no monotonic trend in 238 rainfall pattern between November and February, the period between April and July showed 239 negative trend.

In general, mean monthly rainfall pattern reveals a continuously increasing pattern and

242 probable soil water surplus in the wet season (due to reduced evaporation) that is capable of 243 generating high proportion of overland flow, either as infiltration-excess or saturation-excess 244 (Figure 2a) in the area. The assumption of saturation-excess flow becomes evident with the 245 pattern of measured discharge at the Makurdi station of River Benue, which correspondingly 
246

247 years $\left(y=2968+4.876 x, R^{2}=0.01\right)$, mean annual discharge has relatively declined $(y=109.9-$

$2480.329 \mathrm{x}, \mathrm{R}^{2}=0.08$ ). Increased rainfall has been depicted as hazardous as more communities

249 become vulnerable to flood, and more communities in the study area have become notoriously

250 vulnerable to flooding, and the community and government have appeared to possess no solution

251 or control for years (Ologunorisa and Tersoo, 2006; Ajon et al., 2017). Reduced discharge may

252 be linked with landuse and land cover change (Eludoyin et al., 2017).

\section{Insert Figure 2}

Analysis of the return period for flood incidence reveals that peak discharge in 24 out of the 46 years investigated occurred in September while peaks occurred in November in 20 times, and at only one time did discharge peaked in November. Furthermore, the observed low and statistically insignificant correlation that occurred in annual total rainfall between 1980 and 2017 (Figure 3a), and the wavelet transform result (Figure 3b) reveal low level of similarity in spectral signals (rainfall occurrences) in the area. The low similarity level in the signal reveals the presence of extreme rainfall cases in the wet season. Existing studies showed that the study area experiences wet season whose prevalence is associated with the movement of south westerlies over the Atlantic Ocean (Odekunle \& Eludoyin, 2008). Also, studies (Hula and Udoh, 2015; Agada and Nirupama, 2015) documented that areas in the guinea savanna of Nigeria, including the present study area experience floods more in the wet period. Such documentation will easily associate flood with rainwater overflow due to infiltration-excess or saturation-excess.

\section{Insert Figure 3}


Infiltration-excess flow occurs when the soil infiltration capacity or where when flood is generated due to low infiltration capacity (the maximum rate at which a given soil can absorb precipitation as it falls; Beston, 1964) or where soil storage capacity is extremely low, including poorly vegetated, rocky, paved and concrete surfaces, cultivated and heavily grazed areas (Ziegler et al, 2004; Bilotta, et al., 2007; Kechavarzi, et al., 2010). Saturation-excess flow, on the other hands, prevails at near-stream areas and expansion of small, locally variable water table, during storm condition (Chappell, et al., 2006).

\subsection{Extreme rainfall events}

Results of the SPI indicate alternating wet and dry sequences over the study period; with only $13.5 \%$ of the years exhibiting extreme wetness, and $54.1 \%$ were wet (near normal to very wet) and 32.4\% were dry (Figure 4). In addition, the PCI was 13 - 19.8 units in 2016 and 1982, respectively; indicating moderate-to-high rainfall concentration. Given the SPI and PCI, it is safe to characterize rainfall as being between 'moderately irregular' and 'highly irregular'. Iskander et al. (2014) described areas that are characterised by irregular PCI as that which possesses tendency for high flood potential and consequentially high erosion-potential. The PCI during the 2017 flood event in Makurdi was 18.9 unit, indicating 'highly irregular', and suggesting that flood can be linked with saturation overland flow; flood occurring when the soil is saturated due to rainfall or moisture surplus (see also Olaniran, 1983).

\section{Insert Figure 4}

Also, the number of consecutive rain days peaked between August and September, when the hazardous flood events occurred. Existing studies on Niger-Benue trough and few others settlements in the country confirmed that most hazardous floods occurred in the wet season (Ologunorisa and Tersoo, 2006; Taiwo, 2008), and are therefore triggered by saturation excess 
292 flow, rather than the more spontaneous infiltration excess flow, which probably occurred in local 293 dominance in highly urbanised settlements.

294

295

\subsection{Physical characteristics influencing flood recurrence}

296

The remote sensing-based analysis of relevant physical characteristics of the study area indicated 297 that the communities in Makurdi are within River Benue basin, and are characterized by varying 298 slope; relatively higher in the built-up area than other areas. The northern part of the study area 299 is largely drained by Plinthic Luvisols and fluvisol, while the southern part is dominated by 300 Ferric Acrisols. Both Fluvisols and Plinthic Luvisols are young, weak and poorly drained soils 301 (Batjes, 1997). The soils have derived from the largely sedimentary geology of the crystalline 302 basement rocks (Ofoegbu, 1983). Ofoegbu (1983) noted that part of Makurdi is geologically 303 underlain by three categories of geological composition, namely; alluvium, basalts, trachyte and 304 ryolite as well as shale and limestone. The satellite imagery used in the study also revealed the 305 dominance of alluvium and sandstone in the area (Figure 5d). Alluvium and associated alluvial 306 soil are very productive (Boettinger, 2005), and are therefore vulnerable to pressure for tillage as 307 population increases. In addition, analysis of land cover reveals that a significant portion of the 308 built-up area are concentrated around the River Benue (Figure 5e).

310 Studies (including O'Connell et al, 2007, Konrad, 2016) have established causative links 311 between agriculture intensification, urbanization activities and flooding. In the study area Acha 312 and Aishetu (2018) reported construction and livelihood activities within the Benue floodplain 313 and along waterways. Consequently, the flood vulnerability analysis of the area classified about 
$37.3 \%$ (representing 307.5 sq. $\mathrm{km}$ or $34.1 \%$ of the entire built up area) of the entire land area as medium to high hazard zone (Figure 6).

\section{Insert Figure 6}

\subsection{Flood damage: case study of the 2017 event}

Analysis of some socio-economic variables across randomly selected responses from the study area indicates that the residents of the most affected (flooded) communities in the flood event were relatively poor people (Table 2). Majority of the affected people were working class (aged 25 - 45 years), who's income was at most NGN 600, 000 (US \$1, 520) per annum; about $74.8 \%$ of the respondents have lived for at least 4 years before the flood event and $95 \%$ have experienced flooding events in the study area before the 2017 event. Residential houses with concrete frame and unreinforced masonry was less damaged (damage percentage $=1.8 \%$ ) than residential unreinforced masonry buildings $(22.4 \%)$. The unreinforced masonry structure therefore incurred more damages than concrete frame with unreinforced masonry wall structures (Table 3).

\section{Insert Table 2}

\section{Insert Table 3}

The two indices of flood damage reveal that the unreinforced building and commercial building types were more damaged than the concrete frame buildings. Furthermore, the results of flood vulnerability or depth-damage curves are presented as Figure 7. Figure 7 were generated for dominant building uses (residential and commercial) and type or make-up (Unreinforced Masonry Building or UMB and Concrete Frame with Unreinforced Masonry Building (CFUMB) types). Values of $R^{2}$ (Coefficient of Determination, Wheeler et al, 2013) was low, generally less 
337 than $50 \%$; suggesting that water or flood depth is not a significant predictor of damage to the

338 building and residential contents. Escarameia et al. (2012) argued that other flood characteristics

339 such as duration, velocity as well as variations in building structure and material and responses

340 of affected communities are other factors. Also, damage whereas became obvious at UMB at 20

$341 \mathrm{~cm}$ flood depth, it was at $40 \mathrm{~cm}$ with CFUMB and $23 \mathrm{~cm}$ with the commercial buildings. This is

342 probably because since the floor elevation is first vulnerable (submerged by flood), buildings

343 with higher floors such as the CFUMB were not as damaged as those with lower floor elevation 344 structure.

\section{Insert Figure 7}

In general, only $3.6 \%$ of the total damages occurred with the CFURMB, while the 347 URMB and Commercial Building type experienced 40\% and 34\% damage ratios, respectively 348 (refer to Table 3). Observations from the 2017 flood occurrence reveal that the commercial 349 building type comprises a general set of old or abandoned residential buildings as well as 350 wooden structures that were converted to economic uses. Such wooden and unorganized 351 structures are normally expected to incur high damage ratio at any flood event (Komolafe et al., 352 2018). Also, $81.9 \%$ of the respondents noted that the depth of flood water that displaced the 353 study area between August and September, 2017, was in excess of one meter above the ground 354 level, and the heavy rainfall lasted roughly four days. An average of eight hundred and eleven 355 thousand (NGN 811,814.97 or US\$2, 127.96) was lost by residents whose income (of 86.7\%) 356 was at most NGN 600,000 or US\$ 1572.74 per annum. 


\subsection{Impact of flood warning system}

360 At least $64.3 \%$ of the respondents claimed to be forewarned about the likelihood of a flood event

361 by the Nigerian Meteorological Agency and the Nigerian Association of Hydrological Science

362 but were not sure of the magnitude. Duru (2017) noted that the Benue State Commissioner for

363 Water Resources and Environment noted that they 'were actually aware that there would be 364 flooding but it was the magnitude we (that they) did not know'. With such warning, a youth 365 organization typically embarked on campaign to sensitise the vulnerable communities on 366 cleaning of many blocked drainage channels (Plate 1) that have been implicated for preventing 367 free runoffs, and consequently aggravating flooding.

\section{Insert Plate 1}

369 Also, $73.1 \%$ of respondents argued that construction of more drainage channels could prevent 370 the flooding problem but only $59 \%$ claimed to have received any assistance from the State 371 Government while $12.3 \%$ noted that relatives have provided some aid. However, $81 \%$ of the 372 affected people argued that the responsibility to manage flood disaster in the area is 373 governments' and not residents'.

\section{4. Discussion and conclusion}

375 The study area is typical of communities that are vulnerable to flood in the wet season or during 376 any course of extreme rainfall event, due to their closeness to water bodies. The entire Niger377 Benue region, Niger Delta and coastline of the Atlantic Ocean are vulnerable to flood in Nigeria 378 as many near-stream communities in the world (Ologunorisa \& Adeyemo, 2005; Lindersson et 379 al., 2020). Consequently, flood-related hazards have been referred to as 'natural hazard' even 380 when studies across urban areas in the country (e.g. Omiunu, 1981; Oguntala \& Oguntoyinbo, 381 1982; Olaniran, 1983; Oriola, 1994; Rashid et al., 2007; Adelekan, 2016a, b) and many others in 
382 other parts of the world (Wens et al., 2019; Lindersson et al., 2020) have argued that flood is 383 fundamentally an anthropogenic disaster with strong societal links involving drivers, impacts and 384 feedback mechanisms. A report of the UNISDR (2015) referred to population growth and socio385 economic development in flood-prone areas as the main driver of past decades' flood damages. 386 It is obvious in the study area that the communities are flood prone due to their near-river (River 387 Benue) location and seasonal heavy rainfall. The seasonal heavy rainfall between June and 388 October of every year suggests that the recurring flood disasters are predictable. The perception 389 of early warning by the Nigerian Meteorological Agency is shared by the respondents on the 3902017 flood disaster suggests that the effects can be reduced or avoided, with right responses.

391 When compared with records of flood events in many other areas, it can be assumed that 392 occurrence of flood disasters in many near-stream communities, especially in developing are 393 recurrent and not unexpected but the preventive strategies are either weak or unavailable. 394 Ologunorisa \& Adeyemo (2005) recounted that persistent victims of flood in the Niger Delta are 395 quite aware of the causes of the hazards to include heavy, prolonged rainfall and river overflow 396 but decided to tolerate the hazard for economic reasons (mainly occupational).

397 One striking attributes victims of flood and other disasters in the sub-Saharan Africa is 398 that they are poor and their properties are largely uninsured (NEST, 1991; Odemerho, 1993; 399 Omodanisi et al, 2014) unlike what ensures in many developed countries (Martínez-Gomariz et 400 al, 2020). Like Ologunorisa \& Adeyemo (2005) observed for victims of flood in the Niger Delta, 401 most of the flood victims in the study area were not compensated or given any relief. Also, 402 many of the affected buildings were actually within the floodplain of River Benue or its 403 tributary; analysis of the landuse/cover suggest that about 34\% of the built-up in Makurdi are 
404 within the floodplain of the river. These places easily become submerged with increase in the 405 volume of the river.

406 Furthermore, properties damaged in the 2017 flood hazard were relatively (to the income 407 of the residents) high, and given unreliable/poor insurance policy in the country, poor planning 408 policies and increased rate of land exposure due to urban growth, more records of hazards is 409 predicted. Coping or/and adaptive responses are largely are largely individualistic, and as such, 410 the poor ( $86.8 \%$ who earn at most US $\$ 4.3$; NGN 600,000 by 360 days; Table 2) will be 411 unlikely able to cope, except with government intervention. The huge impact of the 2017 flood 412 disaster after many blocked drainage channels have been cleared in the affected communities 413 suggests that the response was inadequate. In general, the study concluded on the need for an 414 extensive flood control policy for the affected area and similar flood-prone communities. The 415 policy will be strengthened by inclusion of plan for structural control, including channelization, 416 canalization, dredging, building of flood walls and embankments, as well as monitoring and 417 enforcement of the set-back rules to water bodies.

\section{Declarations}

420 Funding: The research was not funded by any governmental or non-governmental institution. 421 Conflicts of interest/Competing interests: There are no competing interest by the authors 422 Availability of data and material: Data are available in repository with the Federal University 423 of Technology, Akure, Nigeria

424 Code availability: Not applicable

425 Ethics approval: Approval to conduct social surveys was obtained through the Federal 426 University of Technology, Akure, Nigeria

427 Consent to participate: All the participating authors agree to participate in the research.

428 Consent for publication: All the participating authors agree to participate to publish the 429 manuscript in this preferred journal. 


\section{References}

431 Acha, S., \& Aishetu, A. (2018). Spatio-temporal changes of land use land cover dynamics and its

432

433

434

435

436

437

438

439

440

441

442

443

444

445

446

447

448

449

450

451

452

453

454

455

456

457

458

459

460

461 implication on urban flood vulnerability in Makurdi, Nigeria. Journal of Research in Forestry, Wildlife and Environment, 10(2), 65-69.

Adelekan, I. O. (2016a). Flood risk management in the coastal city of Lagos, Nigeria. Journal of Flood Risk Management, 9(3), 255-264.

Adelekan, I. (2016b). Ibadan city diagnostic report. Urban Africa risk knowledge.

Adelekan, I. O. (2010). Vulnerability of poor urban coastal communities to flooding in Lagos, Nigeria. Environment and urbanization, 22(2), 433-450.

Adelekan, I. O. (2011). Vulnerability assessment of an urban flood in Nigeria: Abeokuta flood 2007. Natural Hazards, 56(1), 215-231.

Adeleye, B., Popoola, A., Sanni, L., Zitta, N., \& Ayangbile, O. (2019). Poor development control as flood vulnerability factor in Suleja, Nigeria. Town and Regional Planning, 74, 23-35.

Agada, S., \& Nirupama, N. (2015). A serious flooding event in Nigeria in 2012 with specific focus on Benue State: a brief review. Natural Hazards, 77(2), 1405-1414.

Ahmed, A., \& Dinye, R. D. (2011). Urbanisation and the challenges of development controls in Ghana: A case study of Wa Township. Journal of Sustainable Development in Africa, 13(7), 210-235.

Ajon, A. T., Agber, P. I., \& Ali, A. (2017). Runoff, soil loss and nutrient losses from an agricultural field in Makurdi, Benue State, Nigeria. International Journal of Innovative Research and Development, 6(7), 118125.

Albright, E. A., \& Crow, D. (2019). Beliefs about climate change in the aftermath of extreme flooding. Climatic Change, 155(1), 1-17.

Alderman, K., Turner, L. R., \& Tong, S. (2012). Floods and human health: a systematic review. Environment international, 47, 37-47.

Anderson, J. R. (1976). A land use and land cover classification system for use with remote sensor data (Vol. 964(964)). Washington: US Government Printing Office.

Asiedu, J. B. (2020). Reviewing the argument on floods in urban areas. Theoretical and Empirical Researches in Urban Management, 15(1), 24-41.

Atufu, C. E., \& Holt, C. P. (2018). Evaluating the impacts of flooding on the residents of Lagos, Nigeria. WIT Transactions on the Built Environment, 184. 
462 Bai, J., Yu, L., Du, S., Wei, Z., Liu, Y., Zhang, L., Zhang, G. and Wang, X. (2020). Effects of 463 flooding frequencies on soil carbon and nitrogen stocks in river marginal wetlands in a ten-year 464 period. Journal of Environmental Management, 267, p.110618.

465 Baker, J., Chazot, G., Menzies, M., \& Thirlwall, M. (1998). Metasomatism of the shallow 466 mantle beneath Yemen by the Afar plume - implications for mantle plumes, flood volcanism, 467 and intraplate volcanism. Geology, 26(5), 431-434.

468 Barredo, J. I. (2007). Major flood disasters in Europe: 1950-2005. Natural Hazards, 42(1), 125469148.

470 Batjes, N. H. (1997). A world dataset of derived soil properties by FAO-UNESCO soil unit for 471 global modelling. Soil use and management, 13(1), 9-16.

472 Bernhofen, M. V., Whyman, C., Trigg, M. A., Sleigh, P. A., Smith, A. M., Sampson, C. C., 473 Yamazaki, D., Ward, P.J., Rudari, R., Pappenberger, F. and Dottori, F (2018). A first collective 474 validation of global fluvial flood models for major floods in Nigeria and Mozambique.

475 Environmental Research Letters, 13(10), 104007.

476

477 Berz, G. (2000, March). Flood disasters: lessons from the past-worries for the future.

478 In Proceedings of the Institution of Civil Engineers-Water and Maritime Engineering (Vol. 142, 479 No. 1, pp. 3-8). Thomas Telford Ltd.

480 Beston, R. P. (1964). What is watershed overland flow. Journal of Geophysical Research, 69, 481 1541-1552.

482 Beven, K. (1986). Runoff production and flood frequency in catchments of order n: an 483 alternative approach. In Scale problems in hydrology (pp. 107-131). Springer, Dordrecht.

484 Bilotta, G. S., Brazier, R. E., \& Haygarth, P. M. (2007). The impacts of grazing animals on the 485 quality of soils, vegetation, and surface waters in intensively managed grasslands. Advances in 486 agronomy, 94, 237280.

487 Birsan, M. V., Molnar, P., Burlando, P., \& Pfaundler, M. (2005). Streamflow trends in 488 Switzerland. Journal of hydrology, 314(1-4), 312-329.

489 Boettinger, J. L. (2005). Alluvium and alluvial soils.45 - 49

490 Brooks, N., Clarke, J., Ngaruiya, G. W., \& Wangui, E. E. (2020). African heritage in a 491 changing climate. Azania: Archaeological Research in Africa, 55(3), 297-328.

492 Brown, C. A., \& Graham, W. J. (1988). Assessing the threat to life from dam failure 1. JAWRA 493 Journal of the American Water Resources Association, 24(6), 1303-1309. 
533 534

Burrough, P. A. (1986). Principles of geographical. Information systems for land resource assessment. Clarendon Press, Oxford.

Cheval, S., Busuioc, A., Dumitrescu, A., \& Birsan, M. V. (2014). Spatiotemporal variability of meteorological drought in Romania using the standardized precipitation index (SPI). Climate Research, 60(3), 235-248.

Costa, J. E. (1985). Floods from dam failures (Vol. 85, No. 560). US Geological Survey.

Crosier, S. (2004). ArcGIS 9. Environmental Systems Research Institute, Redlands, Calif., USA Davies, R (2017) Nigeria - Thousands Displaced by Floods in Benue State, Flood list. Nigeria Thousands Displaced by Floods in Benue State - FloodList

Davis, E.B., Kimball, C.N., Aten, J.D., Hamilton, C., Andrews, B., Lemke, A., Hook, J.R., Captari, L., Granqvist, P., Hook, J.N. and Davis, D.E. (2019). Faith in the wake of disaster: A longitudinal qualitative study of religious attachment following a catastrophic flood. Psychological trauma: theory, research, practice, and policy, 11(6), p.578.

De Luis, M., Gonzalez-Hidalgo, J. C., Brunetti, M., \& Longares, L. A. (2011). Precipitation concentration changes in Spain 1946-2005. Natural Hazards and Earth System Sciences, 11(5), 1259.

De Risi, R., Jalayer, F., De Paola, F., Carozza, S., Yonas, N., Giugni, M., \& Gasparini, P. (2020). From flood risk mapping toward reducing vulnerability: the case of Addis Ababa. Natural Hazards, 100(1), 387415.

Di Baldassarre, G., Montanari, A., Lins, H., Koutsoyiannis, D., Brandimarte, L., \& Blöschl, G. (2010). Flood fatalities in Africa: from diagnosis to mitigation. Geophysical Research Letters, 37 (22).

Douglas, I., Alam, K., Maghenda, M., Mcdonnell, Y., McLean, L. and Campbell, J. (2008). Unjust waters: climate change, flooding and the urban poor in Africa. Environment and urbanization, 20(1), pp.187-205.

Duru, U. (2017). The role of human activities in streambank stability: Lower Sakarya River (NW Turkey). Journal of Geosciences, 5(3), 130-135.

Ekeu-wei, I. T. (2018). Evaluation of hydrological data collection challenges and flood estimation uncertainties in Nigeria. Environment and Natural Resources Research, 8(2), 44.

Eludoyin, A. O., Akinbode, M. O., \& Okuku, E. (2007, September). Combating Flood Crisis with Geographical Information System: An Example from Akure Southwestern Nigeria. In International Symposium on New Direction in Urban Water Management UNESCO, Paris (pp. 12-14). 
542

543

544

545

546

547

548

549

550

551

552

553

554

555

556

557

558

559

560

561

562

563

564

565

566

567

568

569

570

571

572

573

574

575

576

577

Eludoyin, A. O., Ojo, A. T., Ojo, T. O., \& Awotoye, O. O. (2017). Effects of artisanal gold mining activities on soil properties in a part of southwestern Nigeria. Cogent Environmental Science, 3(1), 1305650.

Eludoyin, O. M., Adelekan, I. O., Webster, R., \& Eludoyin, A. O. (2014). Air temperature, relative humidity, climate regionalization and thermal comfort of Nigeria. International Journal of Climatology, 34(6), 2000-2018.

Escarameia, M., Tagg, A. F., Walliman, N. S. R., Zevenbergen, C., \& Anvarifar, F. (2012). The role of building materials in improved flood resilience and routes for implementation. Comprehensive Flood Risk Management: Research for Policy and Practice, 333.

Fairbairn, A. (2005). A history of agricultural production at Neolithic Çatalhöyük East, Turkey. World archaeology, 37(2), 197-210.

Firth, A. G., Baker, B. H., Brooks, J. P., Smith, R., Iglay, R. B., \& Davis, J. B. (2020). Low external input sustainable agriculture: Winter flooding in rice fields increases bird use, fecal matter and soil health, reducing fertilizer requirements. Agriculture, Ecosystems \& Environment, 300, 106962.

Goes, B. J. M. (2002). Effects of river regulation on aquatic macrophyte growth and floods in the Hadejia-Nguru Wetlands and flow in the Yobe River, northern Nigeria; implications for future water management. River Research and Applications, 18(1), 81-95.

Hillier, A. (2007). Reviews: Think Globally, Act Regionally: GIS and Data Visualization for Social Science and Public Policy Research, by Richard LeGates. Redlands, CA: ESRI Press. 2005. 518 pages. \$64.95 (paperback) Mapping Global Cities: GIS Methods in Urban Analysis, by Ayse Pamuk. Redlands, CA: ESRI Press. 2006. 150 pages $\$ 49.95$ (paperback). Journal of Planning Education and Research, 26(3), 375-377.

Hu, M., Zhang, X., Li, Y., Yang, H., \& Tanaka, K. (2019). Flood mitigation performance of low impact development technologies under different storms for retrofitting an urbanized area. Journal of Cleaner Production, 222, 373-380.

Hula, M. A., \& Udoh, J. C. (2015). An assessment of the impact of flood events in Makurdi, Nigeria. Civil and Environmental Research, 7(10), 53-60.

Hussain, D., \& Khan, A. A. (2020). Machine learning techniques for monthly river flow forecasting of Hunza River, Pakistan. Earth Science Informatics, 1-11.

Iskander, S. M., Rajib, M. A., \& Rahman, M. M. (2014). Trending regional precipitation distribution and intensity: use of climatic indices. Atmospheric and Climate Sciences, 4 (3), Article ID:47852,9 p, DOI:10.4236/acs.2014.43038 
Janerich, D. T., Stark, A. D., Greenwald, P., Burnett, W. S., Jacobson, H. I., \& McCusker, J. (1981). Increased leukemia, lymphoma, and spontaneous abortion in Western New York following a flood disaster. Public Health Reports, 96(4), 350.

Jonkman, S. N., \& Kelman, I. (2005). An analysis of the causes and circumstances of flood disaster deaths. Disasters, 29(1), 75-97.

Kanu, I. A., \& Imatari, E. P. (2020). Africa and climate-related disasters. Tansian University Journal of Arts, Management and Social Sciences, 3(1). 1-8

Kechavarzi, C., Dawson, Q., \& Leeds-Harrison, P. B. (2010). Physical properties of low-lying agricultural peat soils in England. Geoderma, 154(3-4), 196-202.

Knighton, J., Buchanan, B., Guzman, C., Elliott, R., White, E., \& Rahm, B. (2020). Predicting flood insurance claims with hydrologic and socioeconomic demographics via machine learning: Exploring the roles of topography, minority populations, and political dissimilarity. Journal of Environmental Management, 272, 111051.

Komolafe, A. A., Herath, S., \& Avtar, R. (2018). Methodology to assess potential flood damages in urban areas under the influence of climate change. Natural Hazards Review, 19(2), 05018001.

Konrad, C. P., \& Dettinger, M. D. (2017). Flood runoff in relation to water vapor transport by atmospheric rivers over the western United States, 1949-2015. Geophysical Research Letters, 44(22), 11-456.

Kunkel, K. E., Pielke Jr, R. A., \& Changnon, S. A. (1999). Temporal fluctuations in weather and climate extremes that cause economic and human health impacts: A review. Bulletin of the American Meteorological Society, 80(6), 1077-1098.

Latrubesse, E., Park, E., Sieh, K., Dang, T., Lin, Y. N., \& Yun, S. H. (2020). Dam failure and a catastrophic flood in the Mekong basin (Bolaven Plateau), southern Laos, 2018. Geomorphology, 107221.

Lawal, R. (2020, August). Analysis of Petrophysical Properties and Evaluation of Gas Flood Possibilities for Chinese Tight Sandstone Using Pore Network Modelling. In SPE Nigeria Annual International Conference and Exhibition. Society of Petroleum Engineers.

Lekwot, V. E., Kyom, B. C., and Balasom, M. K. (2013). The nature, scope and dimensions of development control, tools and machineries in urban planning in Nigeria. International Journal of Innovative Environmental Studies Research, 1(1), 48-54.

Lindersson, S., Brandimarte, L., Mård, J., \& Di Baldassarre, G. (2020). A review of freely accessible global datasets for the study of floods, droughts and their interactions with human societies. Wiley Interdisciplinary Reviews: Water, 7(3), e1424.

Lovett, A. (2000). GIS and environmental management. In Environmental science for environmental management (pp. 267-285). Prentice Hall, Pearson Education Ltd. Essex, UK. 
634

635

636

637

638

639

640

641

642

643

644

645

646

647

648

649

650

651

652

653

654

655

656

657

658

659

660

661

662

663

664

665

666

667

Martínez-Gomariz, E., Forero-Ortiz, E., Guerrero-Hidalga, M., Castán, S., \& Gómez, M. (2020). Flood Depth-Damage Curves for Spanish Urban Areas. Sustainability, 12(7), 2666.

McKee, T. B., Doesken, N. J. \& Kleist, J (1993) The relation of drought frequency and duration to time scales." Proceedings of the Eighth Conference on Applied Climatology; pp. 179-84. American Meteorological Society, Boston.

Nied, M., Pardowitz, T., Nissen, K., Ulbrich, U., Hundecha, Y., \& Merz, B. (2014). On the relationship between hydro-meteorological patterns and flood types. Journal of Hydrology, 519, 3249-3262.

Nigerian Environmental Study/Action Team, \& International Development Research Centre (Canada). (1991). Nigeria's threatened environment: a national profile. Nigerian Environmental Study/Action Team.

Nkwunonwo, U. C., Whitworth, M., \& Baily, B. (2020). A review of the current status of flood modelling for urban flood risk management in the developing countries. Scientific African, 7 , e00269.

Nwala, B. A. (2017). Press Coverage Of 2012 Flood in Nigeria (A Study of the Guardian, the Nation and the Punch Newspapers). M.A. thesis, University of Nigeria, Nsukka, Nigeria

Nyagba, J. L. (1995). The Geography of Benue State. A Benue Compendium. Denga, DI (ed) Calabar, Rapid Educational Publishers Ltd, 85-97.

Ocheri, M. \& Okele, E, (2012). Social impact and people's perception of flooding in Makurdi town, Nigeria. Special Publication of the Nigerian Association of Hydrological Sciences, 97-105.

O'Connell, P. E., Ewen, J., O'Donnell, G., \& Quinn, P. (2007). Is there a link between agricultural land-use management and flooding? Hydrology and Earth System Sciences Discussions, European Geosciences Union, 2007, 11 (1), pp.96-107.

Odekunle, T. O., \& Eludoyin, A. O. (2008). Sea surface temperature patterns in the Gulf of Guinea: their implications for the spatio-temporal variability of precipitation in West Africa. International Journal of Climatology: A Journal of the Royal Meteorological Society, 28(11), 1507-1517.

Odemerho, F. O. (1993). Flood control failures in a third world city: Benin City, Nigeria-Some environmental factors and policy issues. GeoJournal, 29(4), 371-376.

Ofoegbu, C. O. (1985). A review of the geology of the Benue Trough, Nigeria. Journal of African Earth Sciences (1983), 3(3), 283-291.

Oguntala, A. B., \& Oguntoyinbo, J. S. (1982). Urban flooding in Ibadan: A diagnosis of the problem. Urban Ecology, 7(1), 39-46. 

277.

Olanrewaju, C. C., Chitakira, M., Olanrewaju, O. A., \& Louw, E. (2019). Impacts of flood disasters in Nigeria: A critical evaluation of health implications and management. Jàmbá: Journal of Disaster Risk Studies, 11(1), 1-9.

Oliver, J. (1980). A review of flood problems in tropical Queensland. Disasters, 4(4), 459-468.

683

Ologunorisa, E. T. (2001). An assessment of flood risk in the Niger Delta, Nigeria. Unpublished Ph. D Thesis Department of Geography and Environmental Management, University of Port Harcourt, Port Harcourt.

Ologunorisa, T. E. (2004). An assessment of flood vulnerability zones in the Niger Delta,

684 Ologunorisa, T. E., \& Adeyemo, A. (2005). Public perception of flood hazard in the Niger

685 Delta, Nigeria. Environmentalist, 25(1), 39-45.

686 Ologunorisa, T. E., \& Tersoo, T. (2006). The changing rainfall pattern and its implication for 687 flood frequency in Makurdi, Northern Nigeria. Journal of Applied Sciences and Environmental 688 Management, 10(3), 97-102.

689 Omiunu, F. G. (1981). Ogunpa flood disaster: An environmental problem or a cultural

690 fiction. Aman (Journal of Society, Culture and Environment), 4, 110-121.

691 Omodanisi, E. O., Eludoyin, A. O., \& Salami, A. T. (2014). A multi-perspective view of the 692 effects of a pipeline explosion in Nigeria. International Journal of Disaster Risk Reduction, 7 , $693 \quad 68-77$.

694 Onuigbo, C., ibrahim P.O., Agada, D.U., Nwose I.A. \& Abimbola I. I, (2017). Flood 695 vulnerability mapping of Lokoja metropolis using geographical information system 696 697 698 techniques. Journal of Geosciences, 5(5), 229-242.

699

Oriola, E. O. (1994). Strategies for combating urban flooding in a developing nation: A case

700

701

702

703 704

705

706

707

708 study from Ondo, Nigeria. Environmentalist, 14(1), 57-62.

Oyebande, L. (1991). The role and significance of hydrology and water resources planning in semi-arid and arid tropical environments. In Arid zone hydrology and water resources: papers presented at the international conference held at the University of Maiduguri September 23-26 1985 with the cooperation of UNDP, Lagos (p. 7). University of Maiduguri Press.

Plänitz, E. (2020). Natural Disasters and Political Disorder: Why Urban Flooding Turns Violent. Applying a Fuzzy-set Qualitative Comparative Analysis. Peace Economics, Peace Science and Public Policy, 26(2). 
Ponnamperuma, F. N. (1984). Effects of flooding on soils. Flooding and plant growth, 9-45.

710 Rashid, H., Hunt, L. M., \& Haider, W. (2007). Urban flood problems in Dhaka, Bangladesh: 711 slum residents' choices for relocation to flood-free areas. Environmental Management, 40(1), 95712104.

713

714

715

716

717

718

719

720

721

722

723

724

725

726

727

728

729

730

731

732

733

734

735

736

737

738

739

740

741

742

743

744

745

746

747

748

749

750

751

752

753

Shabu, T., \& Tyonum, T. E. (2013). Residents coping measures in flood prone areas of Makurdi Town, Benue State. Applied Ecology and Environmental Sciences, 1(6), 120-125.

Smit, W., \& Parnell, S. (2012). Urban sustainability and human health: an African perspective. Current opinion in environmental sustainability, 4(4), 443-450.

Sommer, T., Schreier, B., Conrad, J. L., Takata, L., Serup, B., Titus, R., Jeffres, C., Holmes, E. \& Katz, J. (2020). Farm to Fish: Lessons from a Multi-Year Study on Agricultural Floodplain Habitat. San Francisco Estuary and Watershed Science, 18(3), 20p. doi: https://doi.org/10.15447/sfews.2020v18iss3art4

Stopher, P. R., Shen, L., Liu, W., \& Ahmed, A. (2015). The challenge of obtaining ground truth for GPS processing. Transportation Research Procedia, 11, 206-217.

Taiwo, O. (2008). Flood Sacks 500 in Babura. Thisday Media, 13(4867), 18.

Tei, S., Morozumi, T., Nagai, S., Takano, S., Sugimoto, A., Shingubara, R., Fan, R., Fedorov, A., Gavrilyeva, T., Tananaev, N. and Maximov, T. (2020). An extreme flood caused by a heavy snowfall over the Indigirka River basin in Northeastern Siberia. Hydrological Processes, 34(3), pp.522-537.

UNISDR, C. (2015). The human cost of natural disasters: A global perspective. Centre for Research on Epidemiology of Disasters, CRED. PAND report (floodalliance.net).

Wens, M., Johnson, J. M., Zagaria, C., \& Veldkamp, T. I. (2019). Integrating human behavior dynamics into drought risk assessment-A sociohydrologic, agent-based approach. Wiley Interdisciplinary Reviews: Water, 6(4), e1345.

Wheeler, D., Shaw, G., \& Barr, S. (2013). Statistical techniques in geographical analysis. Routledge.

World Meteorological Organisation, WMO. (1989) Calculation of monthly and annual 30-year standard normals, World Climate Programme, Data. WMO-TD/N0 341, WMO. Washington DC World Water Assessment Programme (United Nations), \& UN-Water. (2009). Water in a changing world (Vol. 1). Earthscan.

Yin, C. (2020). Hazard assessment and regionalization of highway flood disasters in China. Natural Hazards, 100(2), 535-550.

Yue, S., Ouarda, T. B., Bobée, B., Legendre, P., \& Bruneau, P. (2002). Approach for describing statistical properties of flood hydrograph. Journal of hydrologic engineering, 7(2), 147-153. 
755 Zeleňáková, M., Gaňová, L., \& Diaconu, D. C. (2020). Flood Damage Assessment and 756 Management, Springer, Cham, https://doi.org/10.1007/978-3-030-50053-5

757

758 Ziegler, A. D., Lim, H. S., Tantasarin, C., Jachowski, N. R., \& Wasson, R. (2012). Floods, false 759 hope, and the future. Hydrological Processes, 26(11), 1748-1750. 


\section{Figures}
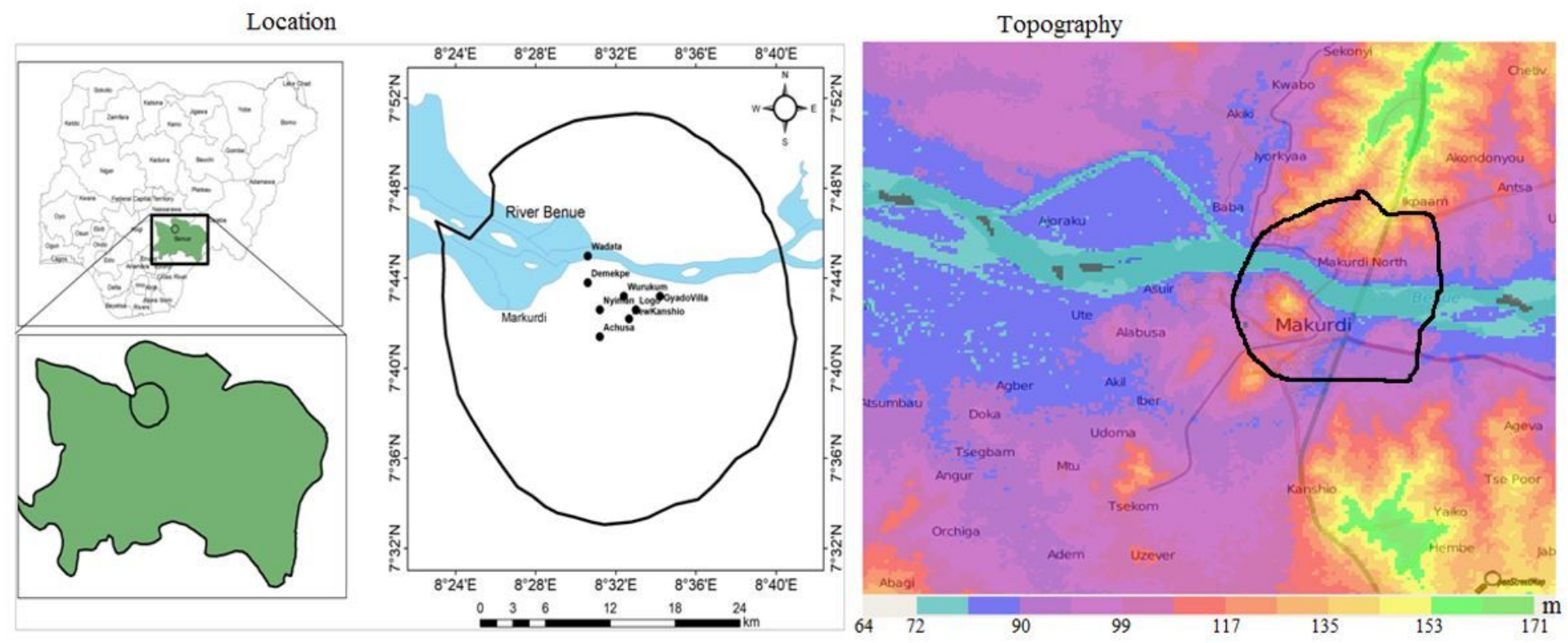

\section{Figure 1}

Location and topography of the study area, Makurdi in Benue State, Nigeria Note: The designations employed and the presentation of the material on this map do not imply the expression of any opinion whatsoever on the part of Research Square concerning the legal status of any country, territory, city or area or of its authorities, or concerning the delimitation of its frontiers or boundaries. This map has been provided by the authors. 
(a)

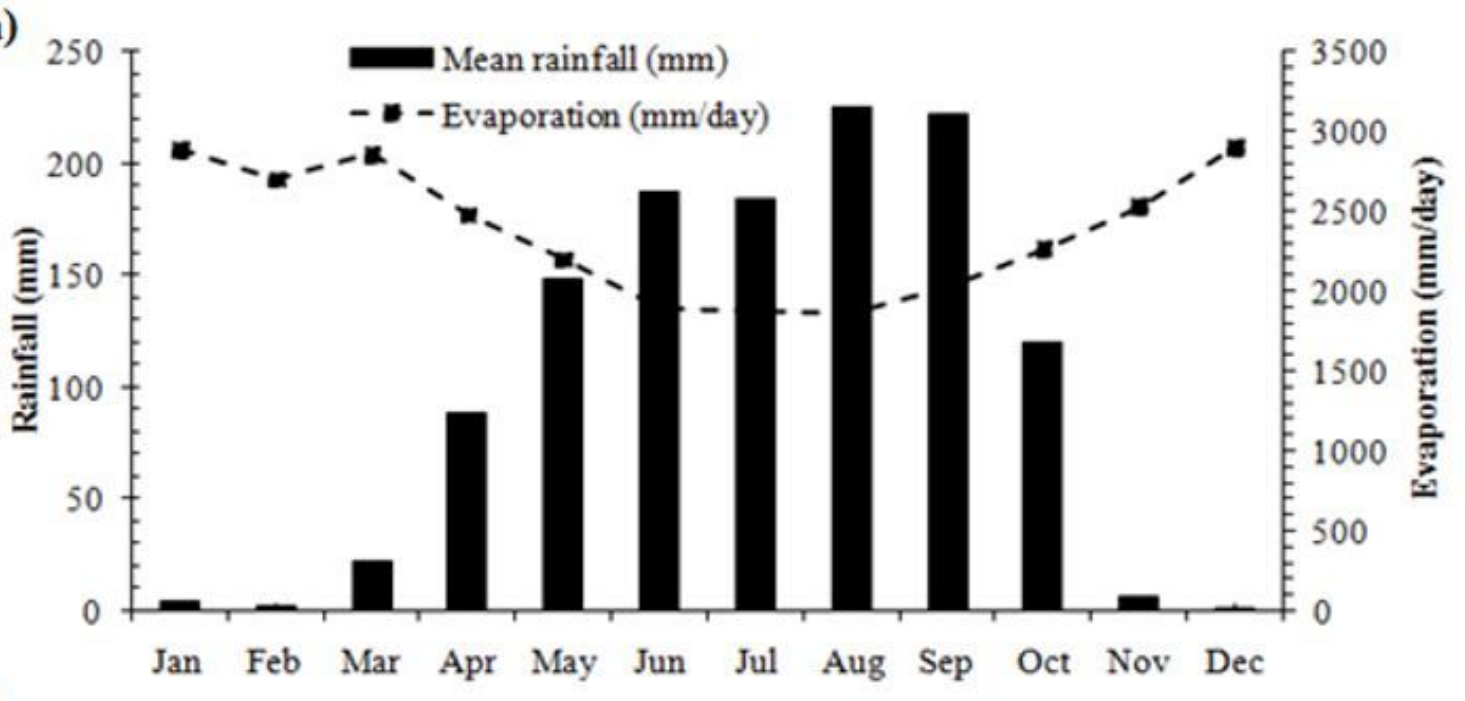

(b)

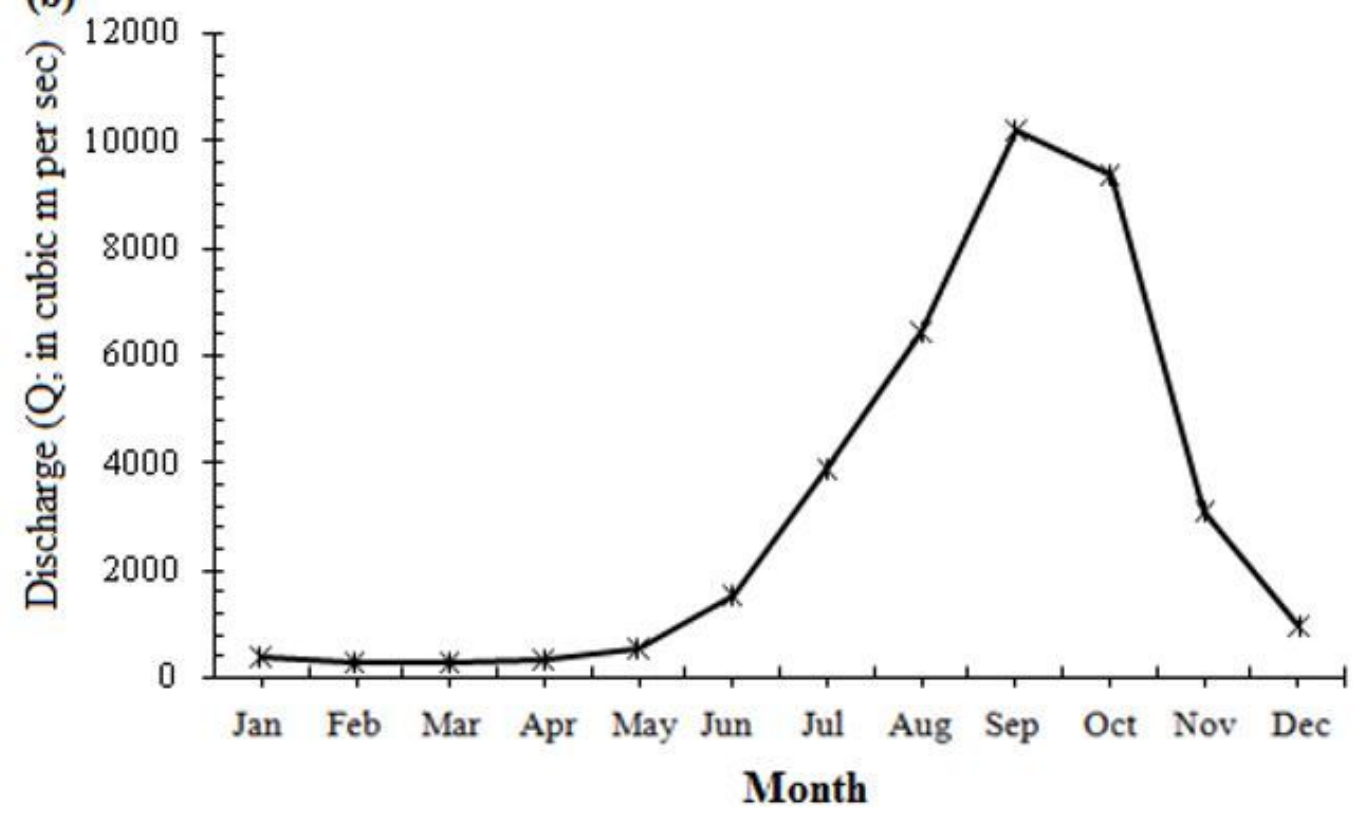

Figure 2

Monthly mean rainfall, evaporation and corresponding discharge of River Benue at Makurdi, Nigeria 

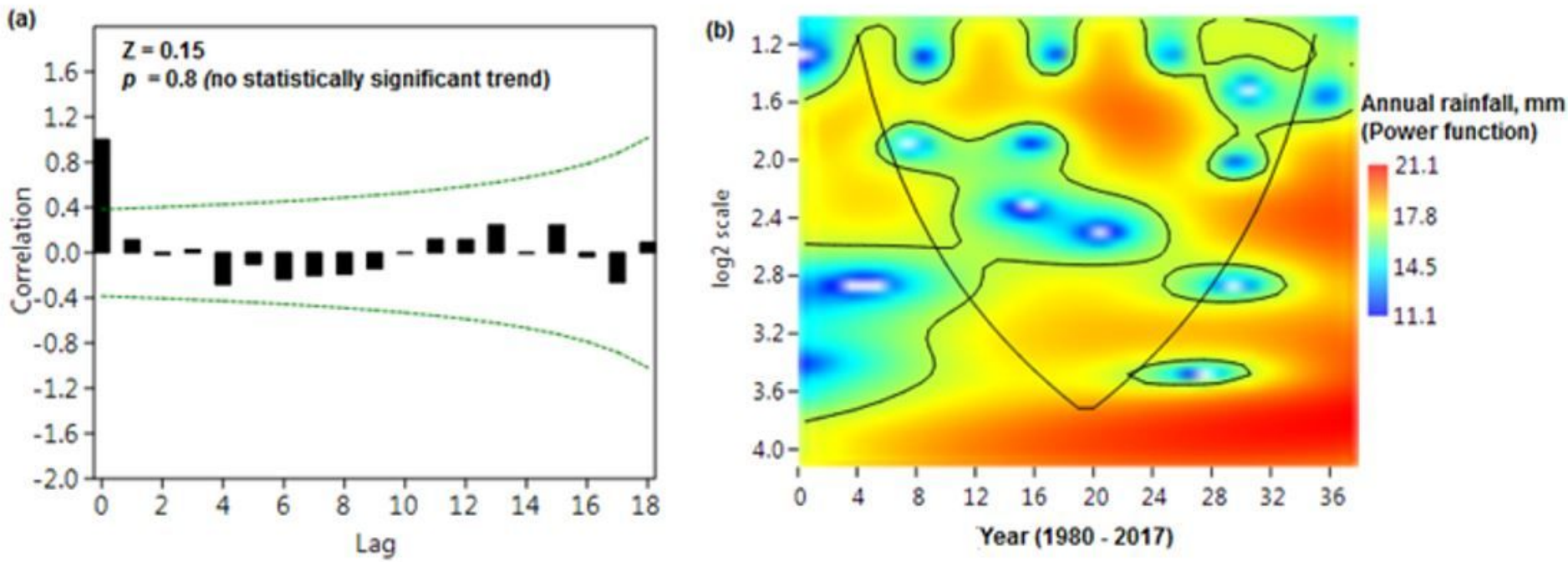

Figure 3

Time-rainfall relationship and variability 

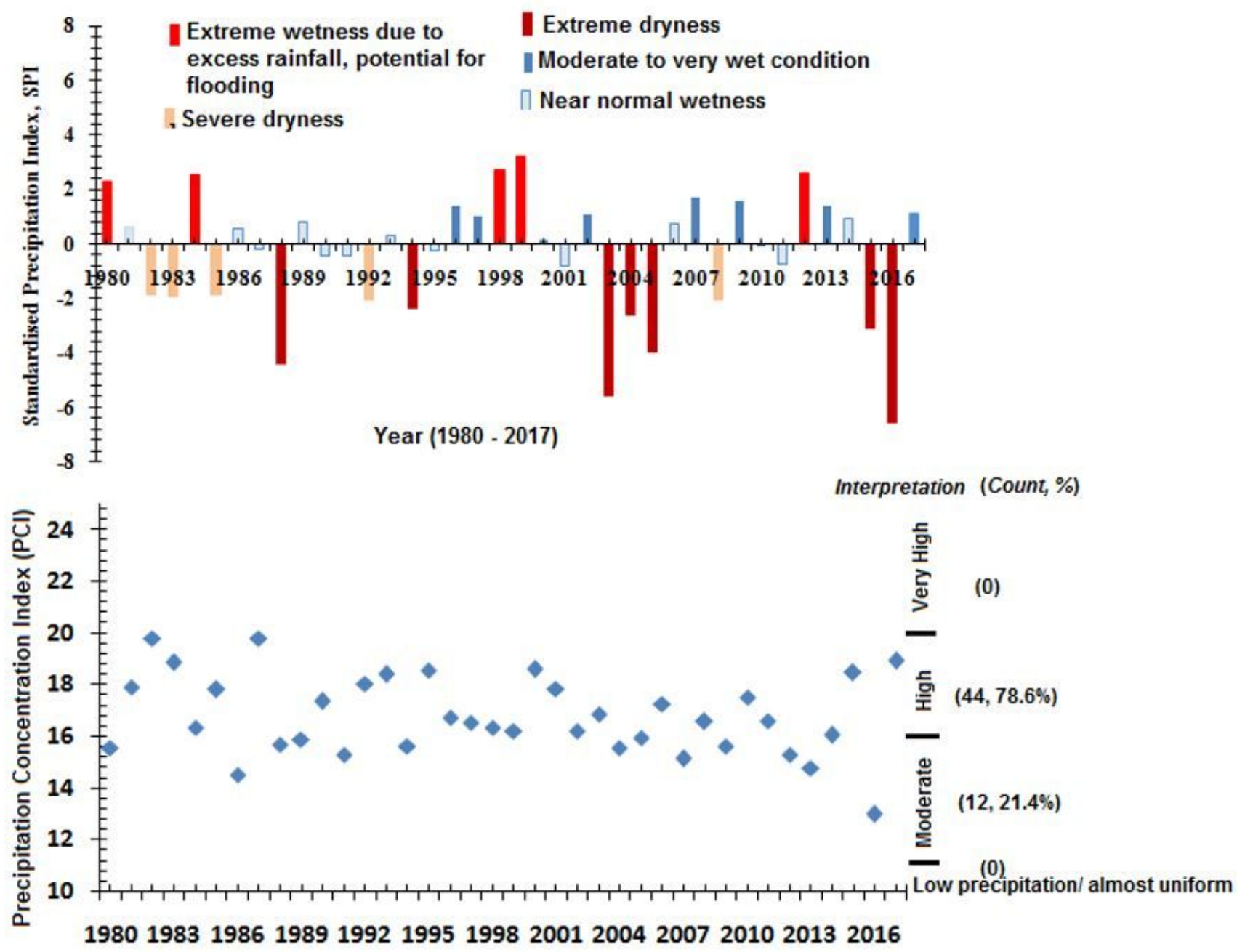

Figure 4

Results of SPI and PCl 
(a). Drainage

R. Benue (b) Slope (degree)

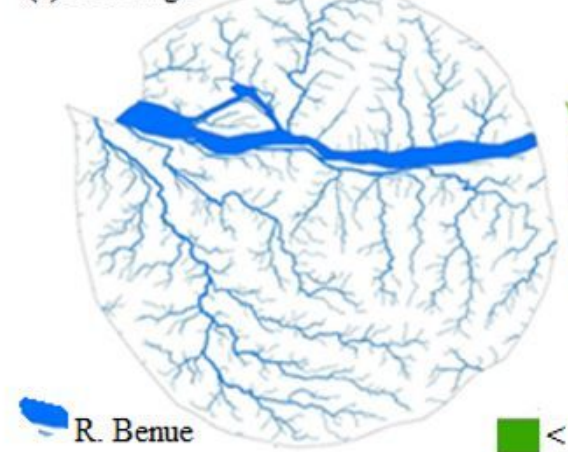

$<1.4$

$1.4-2.6$
)

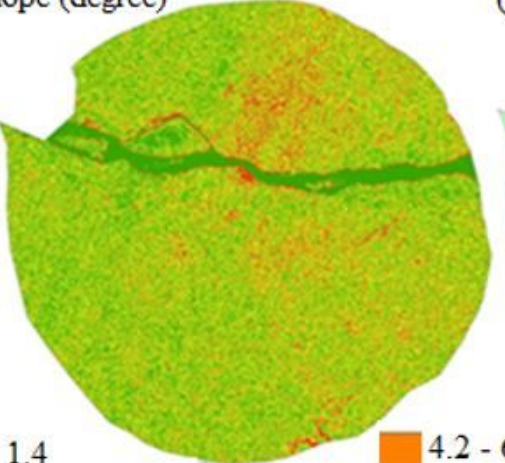

(c). Soil

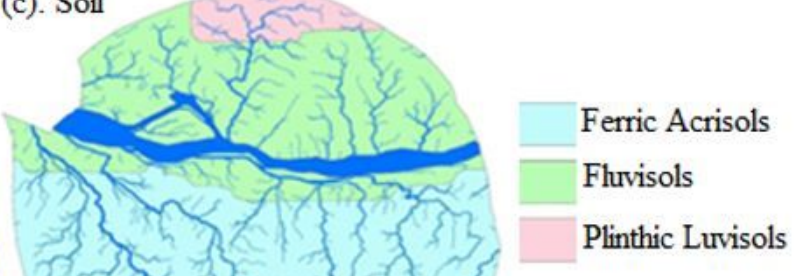

\section{(d). Geology}

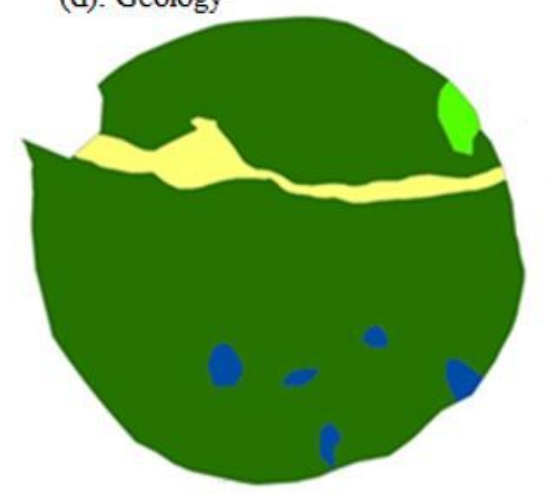

(e) Land cover/use

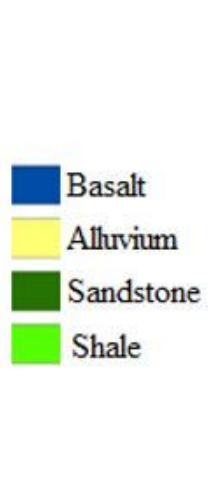

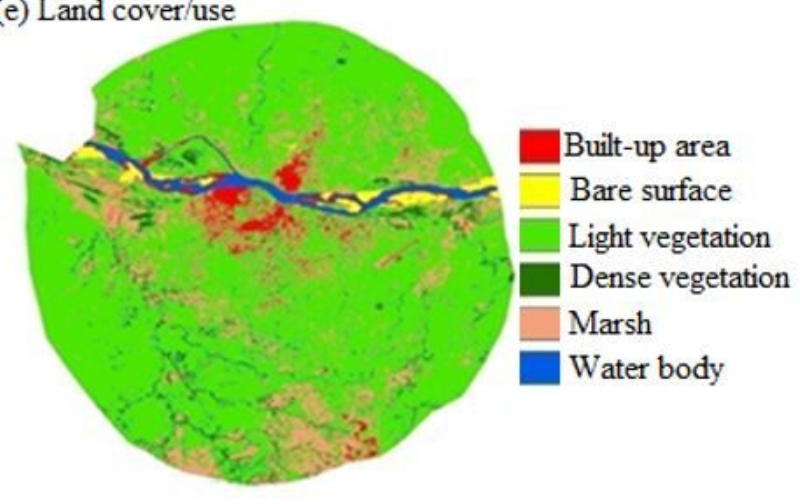

Figure 5

Some characteristics of Benue Basin around Makurdi, the study area 


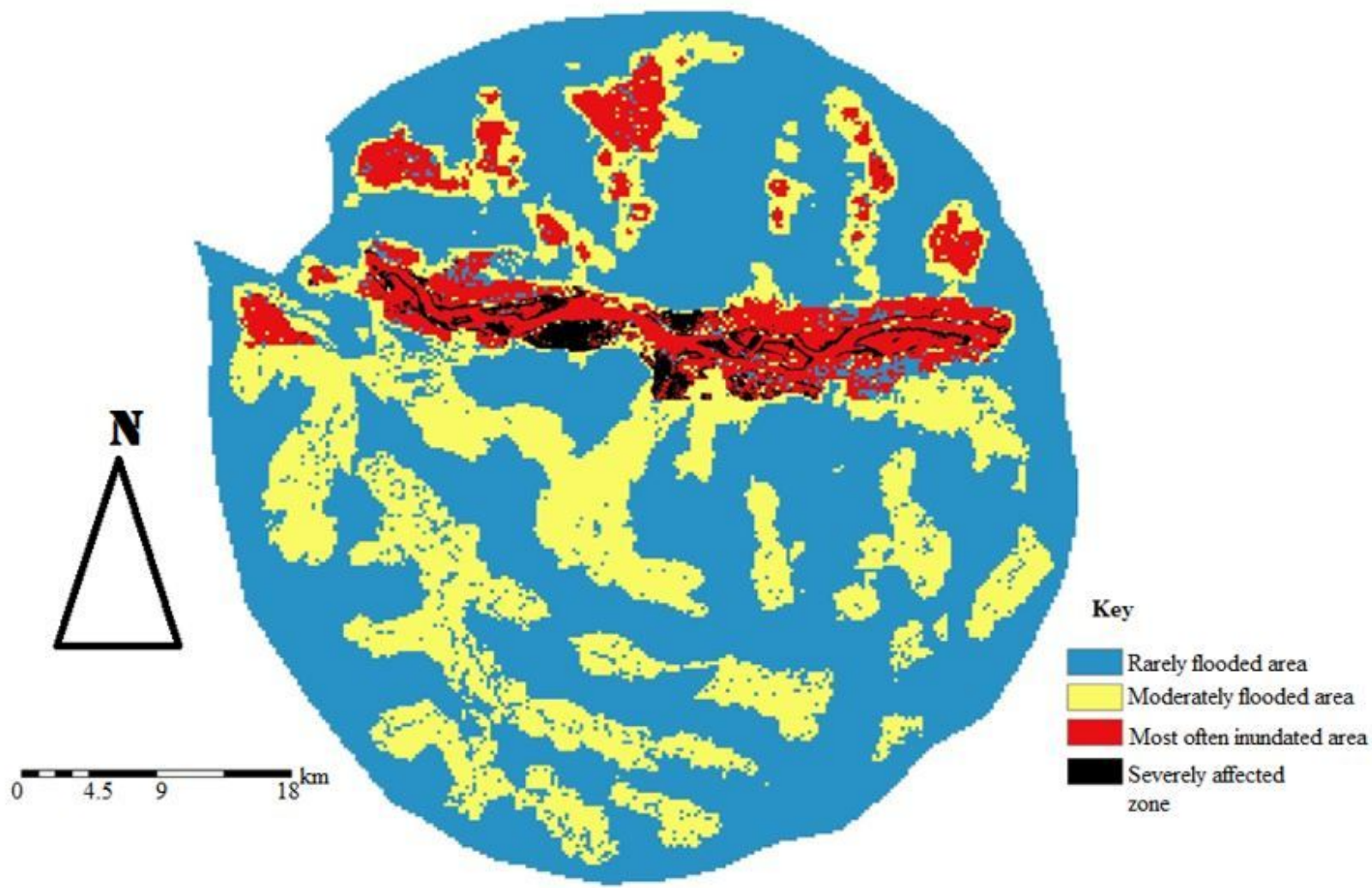

Figure 6

Vulnerability of the study area to flood hazards 


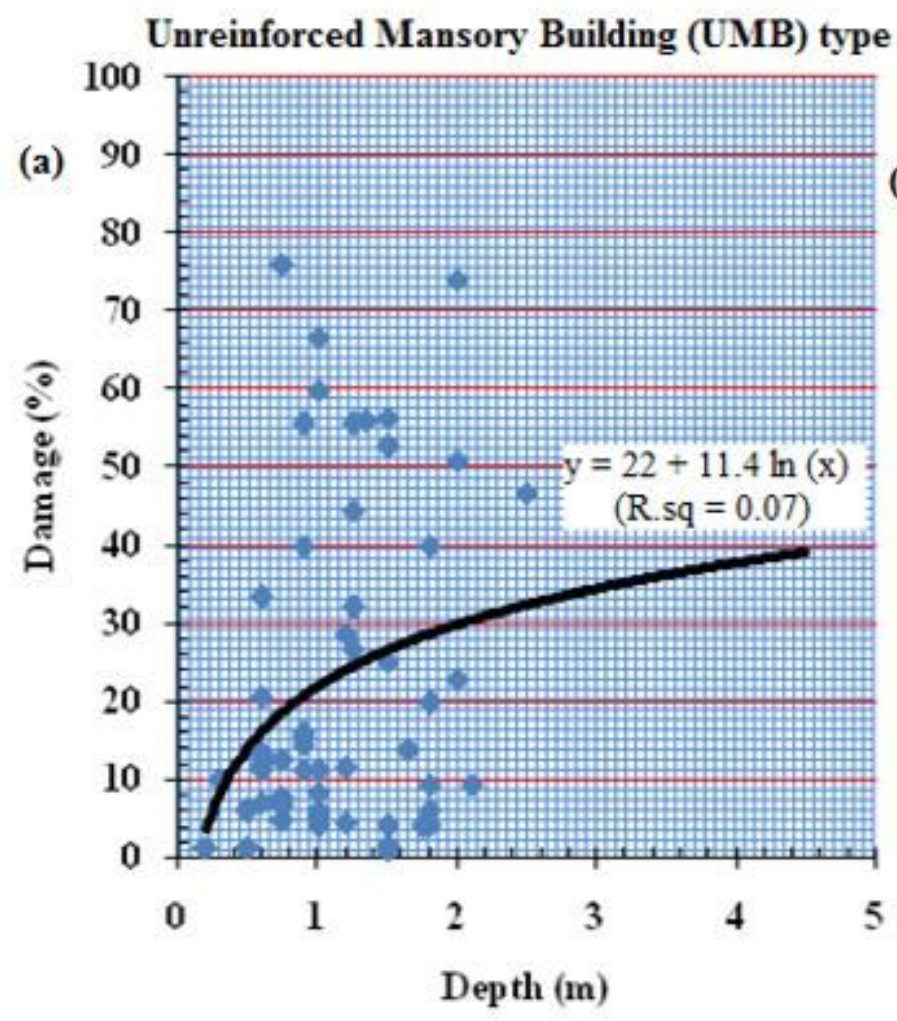

Concrate Frame with UMB (CFUMB) type
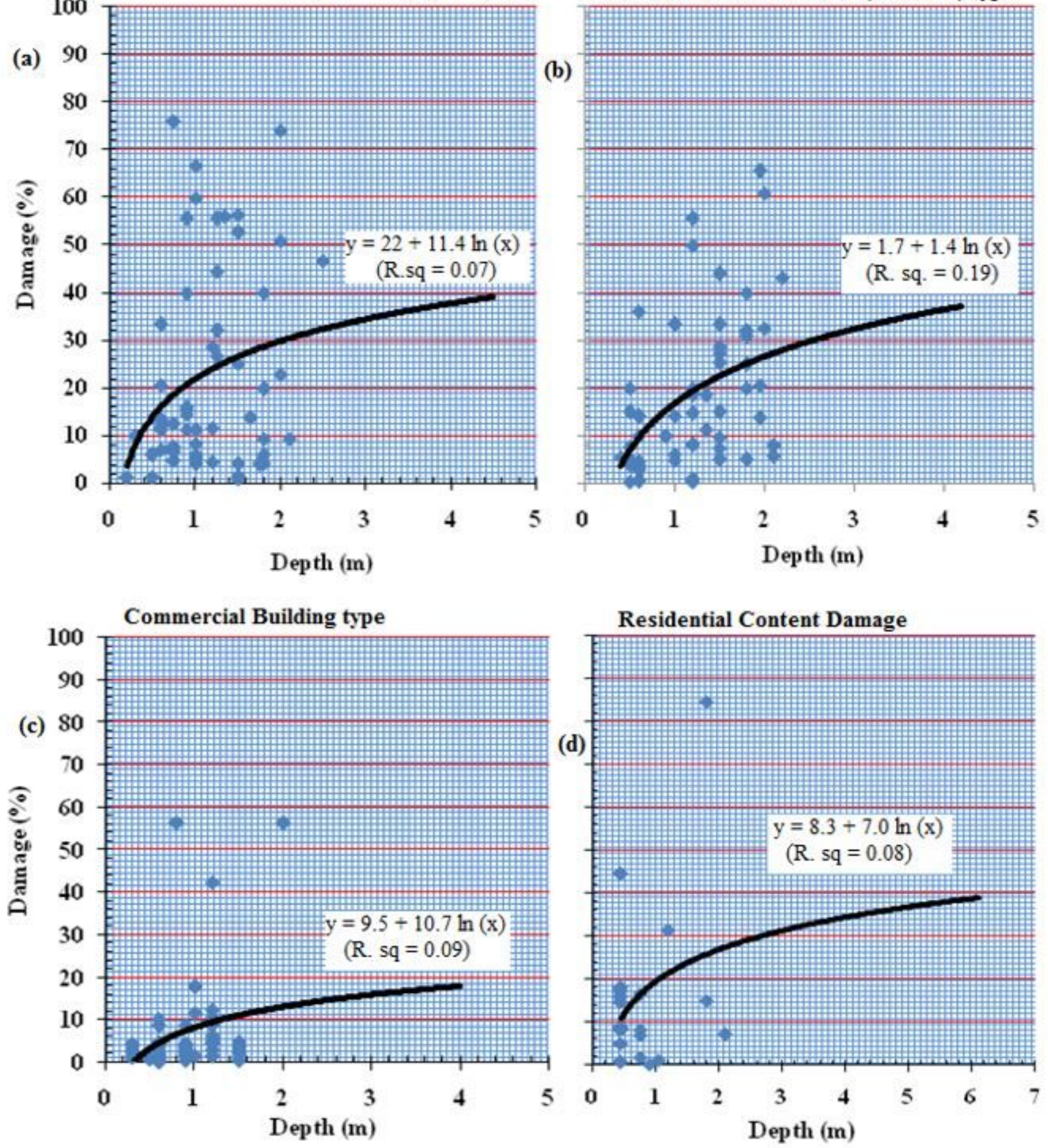

Figure 7

Flood vulnerability or depth-damage curves for different building types in the study area

\section{Supplementary Files}

This is a list of supplementary files associated with this preprint. Click to download. 
- Plate1.jpg 